\title{
Optimal treatment of actinic keratosis
}

\author{
This article was published in the following Dove Press journal: \\ Clinical Interventions in Aging \\ 6 December 2013 \\ Number of times this article has been viewed
}

\section{Gary Goldenberg}

Mount Sinai School of Medicine, New York, NY, USA
Correspondence: Gary Goldenberg Mount Sinai School of Medicine, 1428 Madison Ave, New York, NY 10029, USA

Tel + I 9172099940

Email garygoldenbergmd@gmail.com

\section{Dear editor}

We read with interest the review by Uhlenhake on treatments for actinic keratosis (AK). ${ }^{1}$ The author presents a summary of the various AK treatment options used to reduce the risk of progression to invasive squamous cell carcinoma. The article includes a table (Table 1) comparing advantages and side effects of these options.

Patient-administered topical treatments are an important strategy for treating confluent AKs and areas of sun-damaged skin that may contain subclinical AKs. Rates of complete and partial clearance are similar across the topical agents (fluorouracil, imiquimod, diclofenac, and ingenol mebutate). It is noteworthy that the uniquely brief regimen for ingenol mebutate, 2 to 3 days, produced clearance rates similar to those with the other agents, which have treatment regimens of several weeks. ${ }^{1}$

All of the topical agents are associated with common side effects that include localized erythema, flaking, scaling, and crusting; however, dyspigmentation and scarring occur infrequently. Ingenol mebutate gel is a new topical treatment for AK. Occurrence of dyspigmentation and scarring are rare as there was minimal change in pigmentation and minimal scarring in all groups of the Phase III studies. ${ }^{2}$ Neither dyspigmentation nor scarring are reported among adverse reactions in the Picato package insert. ${ }^{3}$ Localized changes in pigmentation and scarring have been reported with fluorouracil and imiquimod. ${ }^{4-6}$

Localized skin reactions persist during treatment. ${ }^{3-6}$ In my experience, some patients are unable to tolerate prolonged inflammatory skin reactions and may discontinue treatment early, thus failing to achieve the anticipated rates of clearance. The short treatment regimen of ingenol mebutate provides a valuable option for such patients.

\section{Acknowledgments}

Editorial support provided by Tanya MacNeil, $\mathrm{PhD}$ of $p$-value communications.

\section{Disclosure}

Dr. Goldenberg is a consultant, investigator, and speaker for LEO Pharma Inc. and Medicis; he is an investigator for Pharmaderm.

\section{References}

1. Uhlenhake EE. Optimal treatment of actinic keratoses. Clin Interv Aging. 2013;8:29-35.

2. Lebwohl M, Swanson N, Anderson LL, Melgaard A, Xu Z, Berman B. Ingenol mebutate gel for actinic keratosis. N Engl J Med. 2012;366(11):1010-1019. 
3. Picato (ingenol mebutate) gel $0.015 \%, 0.05 \%$ [package insert]. Parsippany, NJ: LEO Pharma Inc; 2012.

4. Aldara (imiquimod) cream, $5 \%$ [package insert]. Scottsdale, AZ: Medicis, The Dermatology Company; 2012.
5. Zyclara (imiquimod) cream $2.5 \%, 3.75 \%$ [package insert]. Scottsdale, AZ: Medicis, The Dermatology Company; 2012.

6. Efudex (fluorouracil) $5 \%$ cream [package insert]. Costa Mesa, CA. Valeant Pharmaceuticals North America; 2006.

\section{Publish your work in this journal}

Clinical Interventions in Aging is an international, peer-reviewed journal focusing on evidence-based reports on the value or lack thereof of treatments intended to prevent or delay the onset of maladaptive correlates of aging in human beings. This journal is indexed on PubMed Central, MedLine, the American Chemical Society's 'Chemical Abstracts Ser- vice' (CAS), Scopus and the Elsevier Bibliographic databases. The manuscript management system is completely online and includes a very quick and fair peer-review system, which is all easy to use. Visit http://www.dovepress.com/testimonials.php to read real quotes from published authors.

Submit your manuscript here: http://www.dovepress.com/clinical-interventions-in-aging-journal 